\title{
Pathological and immunohistochemical findings of a case of canine chagasic myocarditis in the state of Mato Grosso
}

\author{
Aspectos patológicos e imuno-histoquímico de um caso de \\ miocardite chagásica canina no estado de Mato Grosso
}

\author{
Luciano da Anunciação Pimentel ${ }^{1}$; Michelle Igarashi2*; \\ Ana Helena Benetti Gomes 3 ; Livia Saab Muraro ${ }^{3}$; Marcelo Diniz Santos 3 ; \\ Janice Mery Chicarino de Oliveira Coelho ${ }^{4}$; Lázaro Manoel de Camargo ${ }^{3}$; \\ Luiz Claudia Ferreira ${ }^{4}$
}

\begin{abstract}
Dogs are as considered important reservoirs of trypanosomiasis and play a vital role in maintaining the interaction between the domestic and wild cycles of this disease. This paper reports the clinical and pathological findings of a case of Chagas disease myocarditis in a dog from an urban area in Brazil. During clinical examination, the animal showed apathy, weakness and pale ocular mucous and died shortly after. Necropsy revealed ascites, hydrothorax and hydropericardium. The heart was remarkably globoid with scattered multifocal pale in the epicardium and ventricular miocardium and dilated chambers. Histological analysis revealed non-suppurative myocarditis and cardiomyocyte necrosis. The sarcoplasms of cardiomyocytes were frequently infiltrated by $T$. cruzi pseudocysts filled with amastigotes. The myocardium immunostained positive for anti-T. cruzi antibody. The presence of Chagas disease in a dog from an urban area increases the risk of disease transmission to man, which renders this diagnosis a matter of significant public health concern.
\end{abstract}

Key words: Chagas disease, cardiomyopathy, zoonose, dog (Canis familiaris)

\section{Resumo}

Os cães são considerados importantes reservatórios de tripanosomose e têm um relevante papel na manutenção e interação entre o ciclo doméstico e silvestre desta doença. Neste trabalho é descrito as alterações clínicas e anatomopatológicas de miocardite chagásica em um cão, domiciliado em área urbana, no Brasil. Durante o exame clínico o animal apresentava apatia, debilidade e mucosas oculares pálidas, com rápida evolução para o óbito. Na necropsia foram observados ascite, hidrotórax e hidropericárdio. O coração estava globoso com áreas multifocais pálidas no epicárdio e miocárdio ventricular e ao corte observou-se dilatação das câmaras átrio-ventriculares. Histologicamente, no coração havia miocardite não supurativa e necrose de cardiomiócitos. Frequentemente, infiltrando o sarcoplasma de cardiomiócitos, haviam pseudocistos de T. cruzi contendo múltiplas amastigotas. No

\footnotetext{
${ }^{1}$ Prof. Dr., Universidade Federal do Recôncavo da Bahia. Laboratório de Patologia Veterinária, HUMV, Cruz das Almas, BA, Brasil. E-mail: lucianoanp@yahoo.com.br

2 Prof ${ }^{\mathrm{a}} \mathrm{Dr}^{\mathrm{a}}$, Dept ${ }^{\mathrm{o}}$ de Ciências Básicas e Saúde da Faculdade de Medicina, Universidade Federal de Mato Grosso, UFMT, Cuiabá, MT, Brasil. E-mail: michelle.igarashi@gmail.com

3 Profs., Universidade de Cuiabá da Faculdade de Medicina Veterinária, Cuiabá, MT, Brasil. E-mail: ahbenetti@hotmail.com; liviatcho@hotmail.com; marcelo.diniz@kroton.com.br; lazaro.camargo@kroton.com.br

${ }^{4}$ Pesquisadores, Laboratório de Anatomia Patológica do Instituto de Pesquisa Clínica Evandro Chagas IPEC/FIOCRUZ, Rio de Janeiro, RJ, Brasil. E-mail: janice.coelho@ipec.fiocruz.br; luiz.ferreira@ipec.fiocruz.br

* Author for correspondence
} 
exame de imuno-histoquímica, do miocárdio, houve imunomarcação positiva para o anticorpo anti- $T$. cruzi. A ocorrência da doença de Chagas em um canino domiciliado em área urbanizada eleva os riscos de transmissão da doença para o homem, o que consequentemente torna este diagnóstico uma nota de importância em saúde pública e de diferencial para outras patologias caninas.

Palavras-chave: Doença de chagas, cardiomiopatia, zoonose, cão (Canis familiaris)

\section{Introduction}

Chagas disease affects mainly Latin American countries and still represents a major neglected tropical threat to public health, as up to seven million people are estimated to be infected worldwide (WHO, 2015). In addition to humans, its causative agent, the protozoan Trypanosoma cruzi, infects a wide variety of wild and domestic mammals as well as many species of triatomine insects. The main form of transmission of the parasite is by bloodsucking triatomine insects in their sylvatic natural and domestic habitats (VINHAES; DIAS, 2000).

In South America, Triatoma infestans is the main vector of this disease, this is the main reason of a high serological prevalence is also seen in pets such as dogs and cats (GÜRTLER et al., 2007; SOUZA et al., 2009; MENDES et al., 2013). Dogs are considered as reservoirs of $T$. cruzi, and play an important role in the maintenance and the interaction between the domestic and wild cycles of the disease in humans (SOUZA et al., 2008, 2009; SANTANA et al., 2012). Similar to the manner by which humans are infected, dogs contract the disease when they are instinctively infected with the vector faeces, into their own eyes and/or mouth, or into any skin break. Other similar forms of transmission include ingestion of foodstuff containing contaminated vectors and transplacental infection (NISIDA et al., 1999; BEARD et al., 2003). The canine species is the only one known to develop clinical features similar to those presented by humans (SOUZA et al., 2008, 2009; SANTANA et al., 2012). In both species, the disease has three clinical forms: acute, subacute and chronic, and can manifest with cardiac and digestive clinical signs, and less commonly, neurological symptoms (SANTANA et al., 2012; PASCON et al., 2010).
In 2015, the WHO estimated that in Brazil, 1.5 million people are infected by the protozoan and $20 \%$ of the population are at risk of acquiring the infection. Teixeira et al. (2009) suggest that the state of Mato Grosso (MT) is an important geographic area for the epidemiology of Chagas disease, both from vector-borne and oral transmission forms. Research studies on the status of canine Chagas disease in this state are rare (ALMEIDA et al., 2013). This report describes the pathological findings of a case of Chagas myocarditis by T. cruzi in a dog and highlights the importance of diagnosing this disease in these animals.

\section{Case Report}

A three-month old dog (Canis familiaris), cross-breed, from the city of Várzea Grande, Mato Grosso, with a three-day history of apathy and anorexia was seen at the veterinary hospital of the School of Veterinary Medicine, University of Cuiabá, Brazil. During the physical examination, the animal showed apathy, weakness and pale ocular mucous membrane. The dog died during an attempt to venipuncture. Necropsy revealed ascites, hydrothorax, and hydropericardium, formed by translucent slightly yellow liquid, in amounts of approximately $50 \mathrm{ml}, 30 \mathrm{ml}$ and $3 \mathrm{ml}$, respectively. The heart was distended, diffusely pale and presented whitish streaks at the epicardium (Figure 1A). After sectioning, dilation of the atrioventricular chambers, mainly on the right side, and intensely pale, multifocal to coalescent areas were observed (Figure 1B). The lungs were noncollapsed, congested, moderately heavy, presented a shiny surface with mainly pulmonary congestion and edema. A liquid and foamy content was detected 
in the entire trachea. In the liver, there was a focal circular area of subcapsular hepatic hematoma that was slightly elevated on the capsular surface. Following its cutting was friable and bloody. In both kidneys, focally extensive and depressed areas with striated appearance were observed on the capsular surface, which upon sectioning, were observed to extend deep into the cortical parenchyma.

Figure 1. Macroscopic aspects and histopathological analysis of the canine heart with Chagas myocarditis. Globousheart and with whitish striations (arrow) (A). Myocardium with pale areas (arrows) and dilation of the cardiac chambers, $1 \mathrm{~cm}$ bar (B). Non-suppurative myocarditis pseudocysts and T. cruzi amastigotes infiltrating the sarcoplasm containing cardiomyocytes (arrow) H \&E, $50 \mu \mathrm{m}$ bar (C). Myocardial sharp positive immunostaining with anti-T antibody. cruzi, $50 \mu \mathrm{m}$ bar (D).

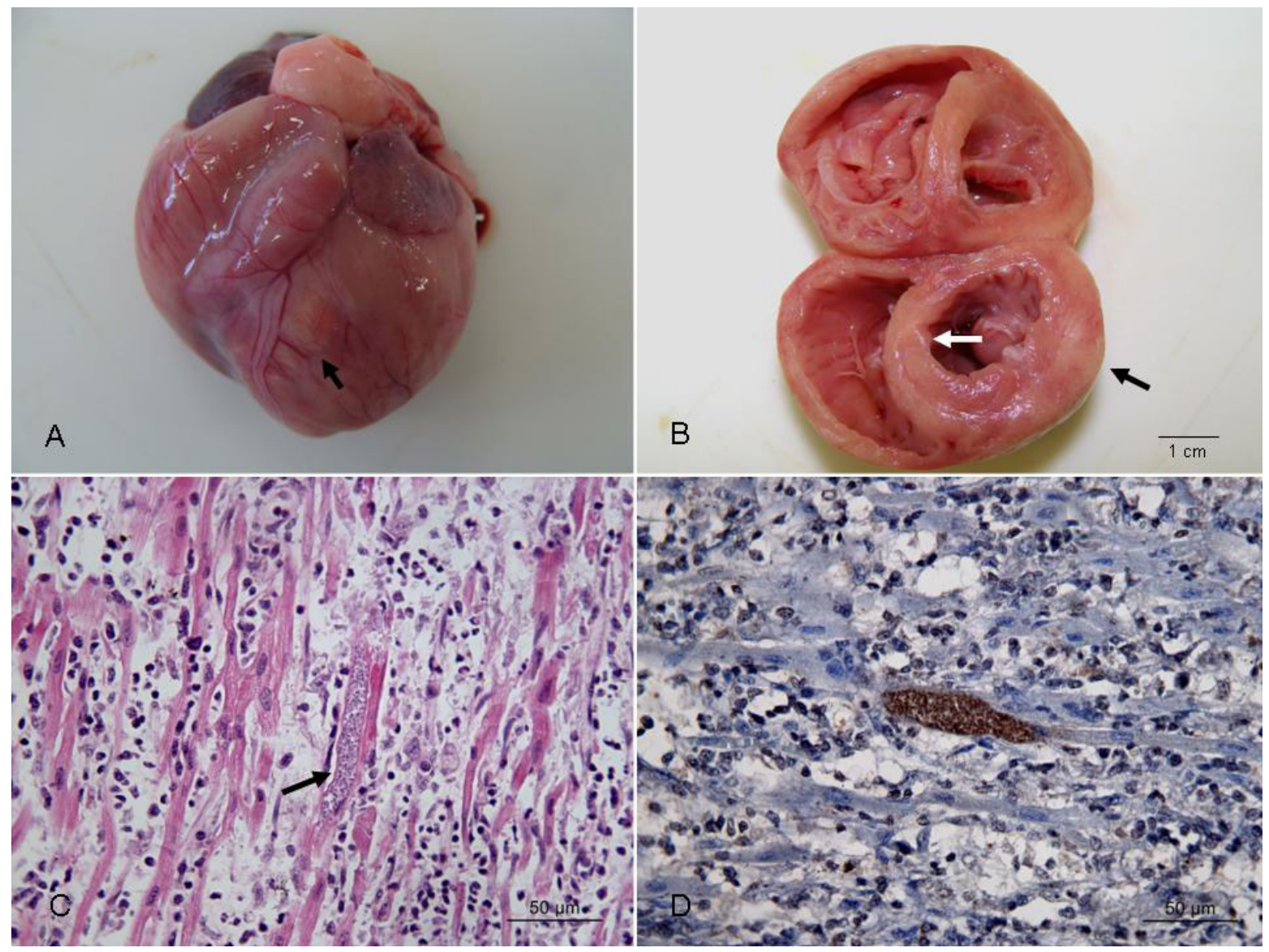

Organ fragments of spleen, intestine, pancreas, stomach, liver, adrenal glands, kidneys, bladder, lymph nodes, esophago, lungs and heart were collected from the abdominal and chest cavities, as well as from the brain, were fixed in $10 \%$ buffered formalin solution and processed for histopathology as described elsewhere (BARROS, 1988).
Histological analysis revealed necrosis of cardiomyocytes and non-suppurative myocarditis with inflammatory infiltrate composed of macrophages, lymphocytes, and plasma cells. Infiltrating the sarcoplasm of cardiomyocytes, round or elongated structures measuring approximately $100 \mathrm{~mm}$ in length, with pseudocysts of $T$. cruzi containing 50-80 amastigotes each, were frequently 
observed (Figure 1C). There was accentuated congestion and mild diffuse intra alveolar edema of the lungs. In the liver, beyond the infarcted area, there was also moderate degeneration and necrosis of hepatocytes, predominantly centrilobular, and diffuse congestion of vessels and sinuses. Kidney lesions with renal fibrosis were consistent with areas of scarring.

Paraffin blocks containing the cardiac muscle tissue fragments were then prepared for immunohistochemistry to detect trypanosomiasis using a biotin-streptavidin-peroxidase kit (Thermo, Rockford, IL, USA). To this end, glass slides containing the target tissue were immersed for 3 min in xylene to eliminate the paraffin, hydrated in decreasing concentrations of alcohol and washed in running water for 10 minutes. To block the endogenous peroxidase, the blades were covered with Peridrol solution and methanol for 40 minutes. Antigen retrieval was achieved by immersing the glass slides in $\mathrm{pH} 6.0$ citrate buffer for 40 minutes. Samples were incubated overnight with the primary anti-T. cruzi antibody diluted in bovine serum albumin (1:600) and washed in pH 7.6 PBS buffer for 5 minutes. Sections were then incubated with the appropriate secondary biotinylated antibody for 30 minutes at room temperature (RT). Streptavidin was added immediately for 30 minutes at RT. Samples were incubated for one minute with the chromogen 3,3'-diaminobenzidine tetrahydrochloride (DAB - Sigma, St Louis, MO, USA). For reaction inhibition, samples were washed in water and counterstained with Harris hematoxylin. Staining specificity was tested by omission or substitution of primary antisera with non-immunized normal rabbit serum. Positive and negative control samples were also prepared from mice infected with $T$. cruzi. As a result, a distinct immunostaining was observed for the anti-T cruzi at the cardiac muscle fragments (Figure 1D). As expected, positive controls showed intense immunostaining of cardiac muscle with the anti-T cruzi.
The other organs colleted, except for the heart, investigated did not present inflammatory changes or the presence of the parasite.

\section{Discussion and Conclusion}

The diagnosis of Chagas myocarditis was based on clinical and pathological findings associated with the identification of parasitic structures consistent with the amastigote form of T. cruzi found by histopathology and the positive immunohistochemical result. The macroscopic (dilated cardiomyopathy) and histopathological findings are characteristic of Chagas myocarditis (PAVARINI et al., 2009). Although the physiological parameters and other clinical changes were not fully evident, the chronic evolution status of the disease was confirmed by the pathological changes due to heart failure such as cavitary edema and the macroscopic alterations observed in the lungs, liver and kidneys. Similar findings were previously reported in dogs that were experimentally or naturally infected with Chagas disease (ANDRADE; ANDRADE, 1980; PAVARINI et al., 2009).

No other known protozoan or infectious agent specifically affects only cardiomyocytes. Taken together, these factors rule out the need for complementary analyses. Molecular assays such as PCR are highly specific tools for the detection of $T$. cruzi infection and are therefore powerful alternatives for the diagnosis of Chagas disease when other techniques such as immunohistochemistry cannot be used (ARAÚJO et al., 2002; NILO JÚNIOR et al., 2013).

On the other hand, serological evidence is necessary to diagnose the subclinical form of the disease (SOUZA et al., 2009; SANTANA et al., 2012). Although a valuable diagnostic tool, serology is limited by cross-reactions with other agents such as protozoan Leishmania sp. Therefore, the use of molecular techniques increases the accuracy of diagnosis of this important neglected disease (ARAÚJO et al, 2002; MORAIS et al., 2013). 
The present study describes the occurrence of Chagas myocarditis in a young dog living in an urban area of Brazil. This certainly raises the risk of disease transmission to humans, which makes it important for the diagnosis to be reported to the public health authorities. Although Almeida et al. (2013) reported natural infection by $T$. cruzi in an adult dog of MT's capital city, Cuiabá, the dog had a history of interaction with the rural area, which is not the case of our canine subject. Previous studies have indicated that, in the countryside, the risk factors for the transmission of Chagas disease to humans involve the contact with dogs and birds infected with the protozoan, and precarious housing structures with mud walls and / or without plaster, which create ecotopes for the vector (TEIXEIRA et al., 2009). Finally, from the point of view of preventive veterinary medicine, Chagas disease should also be part of the differential diagnosis of heart diseases that affect dogs.

\section{References}

ALMEIDA, A. B. P. F.; PAULA, D. A. J.; OTTON, M. L. P.; JAUNE, F. W. J.; CRUZ, R A. S.; MADEIRA, M. F.; NAKAZATO, L.; MENDONÇA, A. J.; PESCADOR, C. A.; SOUSA, V. R. F. Natural infection by Trypanosoma cruzi in one dog in central western Brazil: a case report. Revista do Instituto de Medicina Tropical, São Paulo, v. 55, n. 4, p. 287-289, 2013.

ANDRADE, Z. A.; ANDRADE, S. G. A patologia da doença de chagas experimental no cão. Memórias do Instituto Oswaldo Cruz, Rio de Janeiro, v. 75, n. 3-4, p. 77-95, 1980.

ARAÚJO, F. M. G.; BAHIA, M. T.; MAGALHÃES, N. M.; MARTINS-FILHO, O. A.; VELOSO, V. M.; CARNEIRO, C. M.; TAFURI, W. L.; LANA, M. Followup of experimental chronic Chaga's disease in dogs: use of polymerase chain reaction (pcr) compared with parasitological and serological methods. Acta Tropica, Rio de Janeiro, v. 81, n. 1, p. 21-31, 2002.

BARROS, C. S. L. Guia de técnica de necropsia dos mamíferos domésticos. Santa Maria: Universidade Federal de Santa Maria, 1988. 46 p.

BEARD, C. B.; PYE, G.; STEURER, F. J.; RODRIGUEZ, R.; CAMPMAN, R.; PETERSON, A. T.; RAMSEY, J.;
WIRTZ, R. A.; ROBINSON, L. E. Chagas disease in a domestic transmission cycle in southern Texas, USA. Emerging Infectious Diseases, Atlanta, v. 9, n. 1, p. 103105, 2003.

GÜRTLER, R. E.; CECERE, M. C.; LAURICELLA, M. A.; CARDINAL, M. V.; KITRON, U.; COHEN, J. E. Domestic dogs and cats as sources of Trypanosoma cruzi infection in rural northwestern Argentina. Parasitology, Cambridge, v. 134, n. 1, p. 69-82, 2007.

MENDES, R. S.; SANTANA, V. L.; JANSEN, A. M.; XAVIER, S. C. C.; VIDAL, I. F.; ROTONDANO, T. E. F.; SOUZA, A. P. Aspectos epidemiológicos da Doença de Chagas canina no semiárido paraibano. Pesquisa Veterinária Brasileira, Seropédica, v. 33, n. 12, p. 14591465, 2013.

MORAIS, A. N.; SOUSA, M. G.; MEIRELES, L. R.; KESPER, N.; UMEZAWA, E. S. Canine visceral leishmaniasis and Chagas disease among dogs in Araguaína, Tocantins. Revista Brasileira de Parasitologia Veterinária, Jaboticabal, v. 22, n. 2, p. 225-229, 2013.

NILO JÚNIOR, F. L.; ALMEIDA, V. A.; CARVALHO, F. S.; ALBUQUERQUE, G. R.; SILVA, F. L. First report of Trypanosoma cruzi infection in naturally infected dogs from southern Bahia, Brazil. Revista Brasileira de Parasitologia Veterinária, Jaboticabal, v. 22, n. 1, p. 182185, 2013.

NISIDA, I. V. V.; VICENTE, A. N.; BRAZ, L. M. A.; DUARTE, M. I. S.; UMEZAWA, E. S. A survey of congenital Chagas disease, carried out at three health institutions in São Paulo city, Brazil. Revista do Instituto de Medicina Tropical de São Paulo, São Paulo, v. 41, n. 5, p. 305-311, 1999.

PASCON, J. P. E.; PEREIRA NETO, G. B.; SOUSA, M. G.; PAULINO JÚNIOR, D.; CAMACHO, A. A. Clinical characterization of chronic chagasic cardiomyopathy in dogs. Pesquisa Veterinária Brasileira, Seropédica, v. 30, n. 2, p. 115-120, 2010.

PAVARINI, S. P.; OLIVEIRA, E. C.; BANDARRA, P. M.; LEAL, J. S.; UMEZAWA, I. E. S.; ROZZA, D. B.; DRIEMEIER, D. Miocardite chagásica em caninos no Estado do Rio Grande do Sul. Ciência Rural, Santa Maria, v. 39, n. 4, p. 1243-1247, 2009.

SANTANA, V. L.; SOUZA, A. P.; LIMA, D. A. S. D.; ARAÚJO, A. L.; JUSTINIANO, S. V.; DANTAS, R. P.; GUEDES, P. M. M.; MELO, M. A. Caracterização clínica e laboratorial de cães naturalmente infectadoscom Trypanosoma cruzi no semiárido nordestino. Pesquisa Veterinária Brasileira, Seropédica, v. 32, n. 6, p. 536$541,2012$. 
SOUZA, A. I.; OLIVEIRA, T. M. F. S.; MACHADO, R. Z.; CAMACHO, A. A. Soroprevalência da infecção por Trypanosoma cruzi em cães de uma área rural do Estado de Mato Grosso do Sul. Pesquisa Veterinária Brasileira, Seropédica, v. 29, n. 2, p. 150-152, 2009.

SOUZA, A. I.; PAULINO-JUNIOR, D.; SOUSA, M. G.; CAMACHO, A. A. Aspectos clínico-laboratoriais da infecção natural por Trypanosoma cruzi em cães de Mato Grosso do Sul. Ciência Rural, Santa Maria, v. 38, n. 5,p. 1351-1356, 2008.
TEIXEIRA, A.; VINAUD, M.; CASTRO, A. M. Emerging chagas disease. São Paulo, Bentham e Books, 2009. $191 \mathrm{p}$.

VINHAES, M. C.; DIAS, J. C. P. Doença de chagas no Brasil. Cadernos de Saúde Pública, Rio de Janeiro, v.16, n. 2, p. 7-12, 2000.

WORLD HEALTH ORGANIZATION - WHO. Chagas disease (American trypanosomiasis). Geneva, Switzerland, WHO Editor, 2015. Available at: http:// www.who.int/mediacentre/factsheets/fs340/en/>. Accessed at: 7 ago. 2015. 